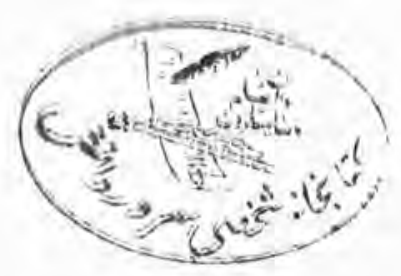

\title{
Wahdat News Bulletin
}

Issued by the Islamic Wahdat Party of Afghanistan (UK)

October 1994

Vol.2 No.13

\section{Editorial}

The past month has seen the sudden escalation of fighting in Kabul. This time, however, the fighting is between the usual coalition of government forces and Sayyaf's Ittihad-i Islami forces on the one hand, and the Waldat Party. supported by the faction of Harakat-i Islami loyal to the Supreme Co-ordination Council, Hizb-e Islani and General Dostom's forces, on the other hand. The entry of the Wahdat Party, so far determined to remain neutral, was forced by the direct bombardment by government forces on residential areas in west Kabul under the protection of the Wahdat Party. The fighting has been fierce, and particularly destructive because of the denselypopulated areas attacked.

This latest round of fighting was instigated following a failed conspiracy by the government, led by the person of Ahmad Shah Massoud, to split the Wahdat Party leadership Council, with the collaboration of the Party's Deputy Secretary-General. Mr Akbari, and Mr Kazemi, member of the Wahdat Party Central Committee. Faced with yet another dead end in its war against General Dostom, following its initial failure to eradicate Hizb-i Islami, the Rabbani-Massoud-Sayyaf coalition attempted to undermine the one remaining non-engaged opponent, the Wahdat Party. Faced with the failure of the conspiracy, and alarmed by the prospect of imminent defeat, the tripartite coalition resorted once again to aggression, this time against the innocent inhabitants of west Kabul, using its most lethal weapon of ethnic differences.

In 'Conspiracy Uncovered' and 'Divide and Rule' we give a detailed account of the developments of the last few weeks, and offer analysis and review of the government's intentions and position. In 'Documents' we reproduce in original and translation copies of documents providing undeniable proof of the government's role - in particular of Massoud's direct involvement - and unquenchable thirst for power,

Meanwhile, the UN perseveres with its relentless efforts to bring together all involved to negotiate for peace. While it has succeeded in securing the co-operation of all other Parties, the determining party to the negotiations, $\mathrm{Mr}$ Rabbani and his government, have so far refused to participate. Indeed the UN's peace process has been matched step by step by obstruction and sabotage by the Rabbani government. As a result, the SICCA has issued a condemnation of the government's refusal, while condoning the UN's efforts and pledging its support for it.
One of the many sad side-effects of the ongoing war of the last 15 years has been the unmonitored and continuous destruction and dispersion of Afghanistan's unique and ancient cultural heritage. WHile the scope of the war's destruction has left little room for such considerations over the years, it is consoling to see efforts being made in this area nevertheless. In publishing the letter from UNESCO we hope to bring this destruction to the attention of as wide a public as possible, while signalling Wahdat Party's support for all such efforts.

\section{MIIIIIIIIIIIIIIIIIIIII I}

\section{NEWS UPDATE}

\section{Ettela'at (International Persian Daily), 12/10/94}

TEHRAN (IRNA) - Foreign Minister, Ali Akbar Velayati told visiting Governor of Western Afghanistan, Ismail Khan, here Monday, that Iran is ready to help the Afghan nation to solve their problems. "Tehran is deeply concerned about the on-going civil war and continued clashes in Afghanistan," Velayati said.

Ismail Khan thanked Iran for its ceaseless efforts in ending fratricide in Afghanistan and urged the Islami Republic to continue its peace efforts.

\section{Radio Spectrum International, 13/10/94}

\section{"800 killed, 17,000 wounded in last 4 weeks of fighting in Kabul"}

According to a report by the radio news service, some 800 people have been killed and 17,000 wounded in renewed fierce fighting in Kabul over the last 4 weeks. Following his refusal to join UN peace gathering in Quetta last month, Mr Rabbani's special envoy is said to be arriving in Pakistan, to join talks organized by the UN Special Commission. An envoy of General Dostom is also said to be arriving.

Mr Rabbani is also said to have agreed to a 3-day ceasefire to allow the delivery of badly-needed supplies to Kabul by the UN.

\section{Le Monde, 14/10/94}

\section{"3-4 million children dead of malnutrition in 15 years"}

AFGHANISTAN: 3 to 4 million children have perished of malnutrition in 15 years. - Three to four million children have died as a result of malnutrition or illness in fifteen years of war and civil war in Afghanistan, declared the UNICEF official responsible for the country, on Tuesday 12 October. Some 50,000 women have died 
in labour during the same period, he added. The organization dedicated to the welfare of children attributes this tragedy to the lack of medical services in AFghanistan. The organization further added that in this Muslim country women cannot refer for treatment to male doctors. (AFP)

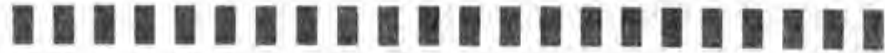

\section{CONSPIRACY EXPOSED}

Last month, a conspiracy intended to remove the Wahdat Party Secretary-General, Mr Mazari, was aborted. The conspiracy was led by Mr Akbari, Deputy to the SecretaryGeneral of the Wahdat Party, and Mr Kazemi, member of the Party's Central Conmittee, in collaboration with government forces. Mr Akbari, who had earlier this year challenged $\mathrm{Mr}$ Mazari's leadership in Party elections and lost, had for some time been in negotiations with Afimad Shah Massoud directly. In an agreement reached, signed and sealed by both men, Mr Akbari was to remove the Party's leader and his followers, in exchange for money and high position, possibly the premiership.

However, the conspiracy, which had for some time been suspected, was exposed and aborted. Of those responsible. many were captured, along with a vast supply of weapons and incriminating documents. Akbari, himiself, took refuge on the government side, while some forty-two of his followers are said to have fled to Iran.

While the conspiracy itself proved totally unsuccessful indeed because of its failure -, government forces, supported as always by Sayyaf's Ittihad-i Islami, began attacking Wahdat Party positions in west Kabul. The Wahdat Party, which had determinedly avoided to engage in fighting since last year, was forced to abandon its neutrality in order to defend its positions. Consequently, the last four weeks have seen renewed fighting in Kabul between government, Sayyaf, and a minority of Harakat forces led by Jawid-Anwari on the one hand, and Wahdat Party, Hezb-e Islami, Dostom and Harakat forces Ioyal to the Wahdat Party on the other. THe fighting has been intense, with densely-populated areas of west Kabul, the last remaining refuge for thousands of war-stricken Kabulis over the past several months, coming under direct fire.

Government sources in Afghanistan have been presenting the fighting as inter-Shi'a factionalism or Shi'a-Sumni in nature. While this is a highly convenient analysis for the government, it is nevertheless totally inaccurate. As the documents reproduced elsewhere in this issue prove a) the government is itself directly responsible for this latest round of fighting, and b) its intention is to undermine the Wahdat Party, rapidly becoming its major opponent in its coalition with the Supreme Co-operation Council (SCC). Meanwhile, the Wahdat Party which has time and again clearly expressed its condemnation of the continuing war in Kabul, and reiterated its belief in pursuing peace through negotiation. It has also actively shown its determination not to engage in fighting itself, unless forced to defend the innocent people of Kabul under its protection.

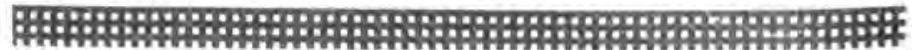

\section{DIVIDE AND RULE}

The Rabbani-Massoud government has once again exposed its factionalist, monopolist and ethno-centric aims and ambitions through its latest machinations in driving a rift between the members of the Wahdat Party Central Comminee, in its attempts to divide and thus undermine its rival, in keeping with the age old tradition of 'divide and rule'. However, once again, while failing to achieve its aim - for although a conspiracy was attempted - it was aborted by forces to Mr Mazari who had been aware of and in waiting for the attempt, the govermment managed to strike yet another own goal by undermining its own credibility.

Ever since seizing power, the Rabbani-Massoud leadership has been portraying itself, for both internal and external observers, as a 'moderate' government of national reconciliation and unity, as opposed to its alleged 'fundamentalist' and destabilising rivals. An image in keeping with the expectations and policies of those outside Afghanistan who supported this government misguidedly at the outset, and continue to support it now it seems out of sheer convenience and lack of proper understanding of developments in Afghanistan. However, this most recent act of sabotage, attested to as it is by documents available, shows this government in its true light, in total contradiction of this image. (See DOCUMENTS)

Not only is this not a government of reconciliation and unity, if actively promotes, indeed relies upon, religion and thuic conflicts and differences. It is quite happy to set Pashtun against Hazara, Sunni against Shi'a, etc, in the process of annihilating and undermining its rivals and enemies. This was its real aim in conspiring with Akbari and Kazemi. This is also why the Akbari conspiracy is of importance, For while the potential instability of this episode for the Wahdat Party is of importance, its true significance lies in its exposition of this government. This willingness to re-open deep seated historical conflicts is truly dangerous and should serve as a warning of the implications of this government's continued hold on power.

This tendency is also in complete contrast to Wahdat Party's, and in particular Mr Mazari's, belief in and efforts at actively encouraging unity between different ethnic groups in Afghanistan. This is undeniably evident in his success in bringing together in co-operation. Pashtuns (Hezb-i Islami), Uzbek (General Dostom and his followers) and even Tajiks in the Supreme Co-ordination Council (SCC), not to mention his relentiess calls for peace through negotiation.

Of course, this latest machination is the most recent in a series of such attempts at perpetuating the war. This goverument has so far aborted two major international peace efforts: one at the time of the transfer of power from the Najibullah government to the Mujahideen, and more recently, efforts by the UN special Commission, led by $\mathrm{Mr}$ Mestiri. When, after months of preparation, involving a somewhat hazardous fact-finding trip inside Afghanistan, $\mathrm{Mr}$. Mestiri proposed the convening of a pre-peace 
conference gathering in Quetta in September, $\mathrm{Mr}$. Rabbani refused to participate, in objection to General Dostom's participation. Previously also the 'Herat fiasco' had already signalled the goverument's lack of respect for the international community's efforts for peace.

This government has shown time and again, both in its internal and international policies, that not only is it not the 'moderate' force claimed in its rhetoric, but is itself guilty of the kind of extremist and destabilising policies it bas continuously accused its rivals of. Furthermore, not only does it not have the least interest in seeing peace restored in Afghanistan, but is acively engaged in perpetuating the war. More dangerously, not only has it opted for war as a means of succeeding over its opponents - instead of pursuing any kind of political settlement - but it is willing to use Afghanistan's atomic bomb, its dormant historical ethnic couflicts, to this end; a weapon that could truly annihilate Afghanistan once and for all.

\section{The Harakat Experience}

The Wahdat party is not the government's only rival to have been the target of factionalist sabotaging. The Harakat-e Islami led by Sheikh Asef Mohseni at the time of the Mujahideen liberation of Kabul, no longer exists as an organisation. As the result of an conspiracy similar to the Akbari betrayal, an equally mercenary faction of the Harakat led by Messrs. Javid and Anwari, managed to bring about the division of the organisation. As a result, Harakat is now split into three factions, each on totally opposing sides. While one group remains under the continued but inactive leadership of Sheikh Mohseni from his headquarters in Peshawar, a second is composed of disorganised and semi-autonomous bandits under the ineffective leadership of the Javid-Anwari duo, in the service of that other infamous duo, Rabbani-Massoud. A third faction, based in northern Afghanistan, with some territory in Kabul, has joined the SCC, working in close co-operation with the Wahdat Party. Indeed, it was elements from Harakat who first alerted the Wahdat Party leadership to the imminence of the Akbari conspiracy.

\section{Price of Democracy}

The existence of political differences and factionalism is not of course uncommon or unusual in itself. It is part of the political development of all countries; the most relevant example with relation to the UK is the formation of the Social Demecratic Party by a breakaway group of labour politicians in the 1980s. This is perfectly legitimate once differences in ideology become deep enough and polarising. In the case of the Akbari conspiracy and the Wahdat Party however, there is neither evidence of ideological differences, nor is a conspiracy the politically acceptable means of expressing differences. Instead, this was an illegitimate leadership challenge by Akbari, who having lost in legitimate party elections held in June simply chose to resort to treason. By offering himself to a higher bidder in exchange for money and arms he not only reaffirmed Mr. Mazari's right to lead the Wahdat Party, but exposed his own indifference and contempt for the democratic procedures on which the Wahdat Party has insisted under Mr. Mazari's leadership, and which no other party in Afghanistan has abided by. So that if the Massoud-Rabbani duo were able to infiltrate the Wahdat Party at all, this is the inevitable outcome of the Party's democratic beliefs, in keeping with which it has not only tolerated challengers but has kept them in positions of power to which they were voted by their respective followers, instead of suppressing political differences within the Party. And while such a price is bitter and potentially dangerous, it is nevertheless worth paying for democracy.

What Afghanistan needs at present are movements and policies encouraging national unity, the reconciliation of multifarious conflicts, and the creation of security, to encourage all, political groups and ordinary people, to concentrate all their forces and energy on establishing peace, reconstructing the country, and preparing for the return of the world's largest refugee reputation.

What the current goyernment's poticies have achicved so tar has been the exact opposite. While it has singularly failed to take any steps in these directions, it has continued to refuel the war, each time using a more dangerous weapon. If it is not stopped soon, Atghanistan will no longer just be a lost cause. it will simply be wiped off the political map of the world.

\section{DOCUMENTS}

In the aftermath of the failure of the conspiracy by Wahdat Party's Deputy leader. Mr Akbari, in collaboration with Ahmad Shah Massoud and Ministry of Defence forces, documents incriminating those involved beyond doubt were seized at the time of the arrest of several of the co-conspirators. Here we reproduce just two which we believe are of particular significance. Document 1 clearly attests to the government's involvement and intentions, highlighting Massoud's direct personal participation. Document 2, by far the most revealing, attests to this government's ruthlessness and willingness to exploit the dangerous historical ethuic complexities of Afghanistan, without concern for its guaranteed horrific consequences, putting the lie once and for all to its claims of pursuing national reconciliation and peace.

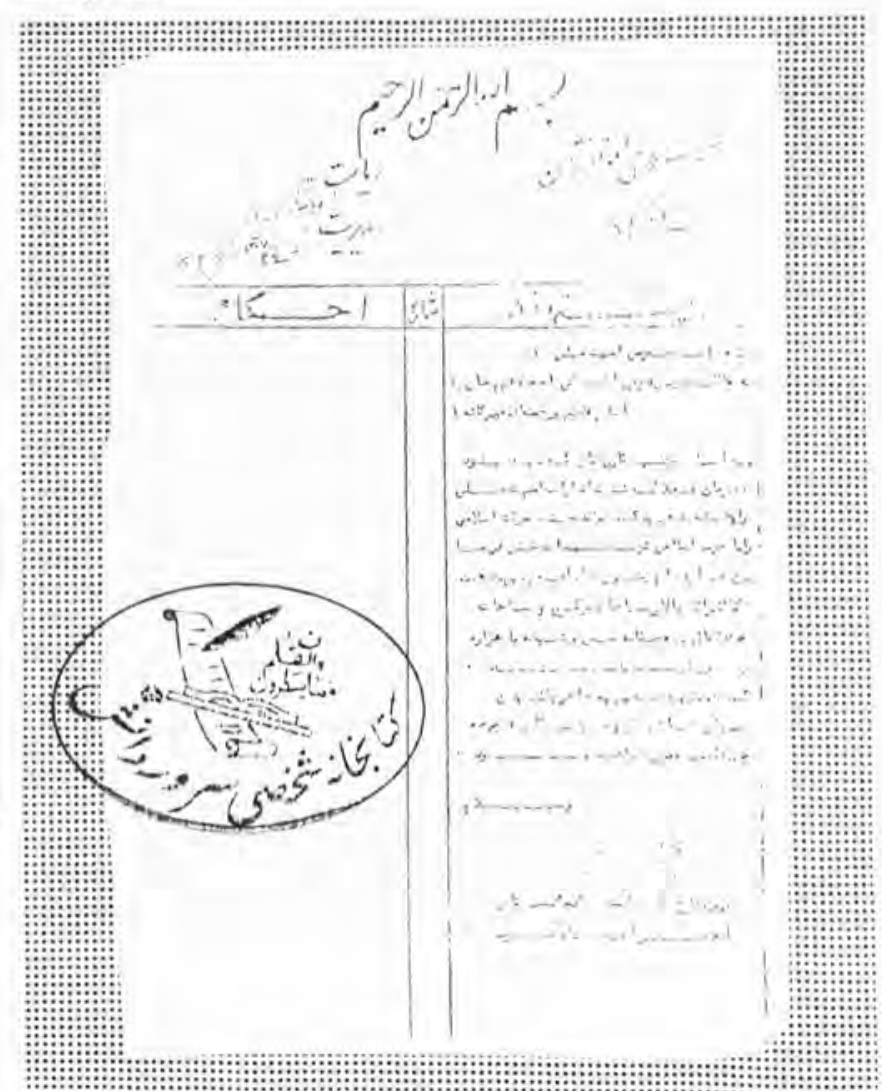




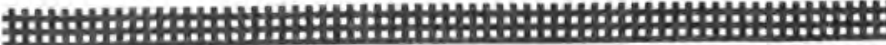

\section{Statement by the Islamic Wahdat Party of Afghanistan Central Committee in Condemnation of the Recent Conspiracy}

(The following are excerpts from the original text).

The ruthless and war-mongering gang of Showra-ye Nizar and Sayyat's Ittihad-e Islami, which throughout the past two and a half years has repeatedly drawn out the sword of violence and barbarism, and ruthlessly and vengefully killed oul freedom-loving people in order to destroy our dignity and honour.... has once again ... conspired with infamous and dastardly elements in the Harekat-i Islami and weakwilled and cowardly elements in the Islamic Wahdat Party (IWP) to dissolve the IWP. [And] intended to repeat the bitter and horrific Afshar tragedy and to cover up their disgraceful defeat in the rest of the country by undermining the proud leadership of the IWP, in order to capture positions held by our honourable and freedom-loving people.

The enemy and its wretched servants have spent fruge sums of money and made extensive preparations to this end, in the belief that their success was assured.... But. as the will of God never coincides with the ignoble will of villains, tyrants and impostors, this ... conspiracy was uncovered and quickly aborted by the courageous and vigilant forces of the IWP, with the co-operation of the vast majority of the decent and compassionate mujahideen forces of the Harekat-i Islami. In consequence, the enemy"s wishful fantasies of seizing control over the destiny of our faithful people were abruptly ended.

But the infamous Showra-ye Nizar and Sayyaf's Ittihad forces, alarmed by this massive defeat and fearing their own imminent annihilation, have in retaliation resorted to launching a barbaric and destructive military offensive against positions held by the IWP and the residential districts of west Kabul, carrying out direct bombardments and rocket attacks [on these areas], and committing horrific crimes.

Meanwhile, unfortunately, mercenary elements harbouring ill feelings against the people have served to pave the way for the enemy. Prepared to stab our people from behind, they have attacked our honourable fellow Muslims.... delivering positions in Dasht-i Azadegan and several other areas into the hands of the wounded and vengeful enemy..., standing by while their bloody hands committed murder and pillage against innocent and defenceless people.

The Islamic Wahdat Party Central Commidee (IWPCC)...proclaims the following:

1. The IWPCC condemns unreservedly the recent conspiracy undertaken by elements whose anti-nationalist ideology is known to all, and their collaboration with our sworn enemies as dastardly and contenuptible.

2. The IWPCC condemins the barbaric assault by the Showra-ye Nizar and Sayyaf's Ittihad forces on Wahdat Party positions and in particular on residential areas, and calls on the Party's brave Mujahideen fighters to continue to resist the assault, in the defence of our people's dignity and honour.
3. The IWPCC calls on all vigilant fellow Muslims, beloved protectors and brave soldiers to continue their resistance with ever closer co-operation and resilience, and in particular to expose and dishonour those traitors who collaborated with the enemy at the expense of our children's blood.

4. The IWPCC condemns the horrific massacre of innocent people by the enemy's servants in Dasht-i Azadegan, and considers it an inhumane and un-islamic act of utter vengeance, and calls on the brave fighters of the IWP to refrain from seeking vengeance in cleansing these areas of mercenary elements and to exercise restraint and forgiveness.

5. The IWPCC, in the limmediatel aftermath of the uncovering of the recent conspiracy, was utterly opposed to the escalation of war and killing, and called for a ceasefire and the restoration of peace. However, it shall contimue to steadfastly and assuredly defend innocent people and its positions against the direct aggression and invasion by its wounded enemy.

Islamic Wahdat Party of Afghanistan Central Committee 21 September 1994

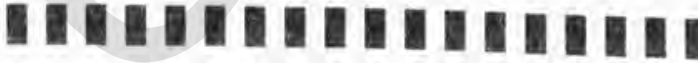

\section{Statement by the Supreme Islamic Cooperation Council of Afghanistan (SICCA) on UN's Peace Efforts}

Following the conclusion of its fact-finding mission inside Afghanistan, the UN Special Commission for Afghanistan, led by Mahmood Mestiri, launched phase two of its peace plan by inviting all Parties to participate in preliminary talks in Pakistan last month. Mr Rabbani, who had already chosen to ignore the UN efforts on several occasions, refused to participate in objection to the inclusion of General Dostom's Jonbesh in the proceedings, thereby
obstructing the peace process.

The following statement was issued by the Supreme Islamic Co-ordination Council of Afghamistan (SICCA) in response to $\mathrm{Mr}$ Rabbani's refusal to co-operate. In th the SICCA calls on Mr Mestiri to persevere with the peace process, lending its unqualified support to it, and condemns the Rabbani government for obstructing this and
other UN initiatives for peace.

Following the establishment of the Islamic government in Kabul, and throughout the 2-month interim leadership of Haztat Mujaddedi, those currently in power continuously reneged on the commitments and agreements reached. When Mr Rabbani's four month in office finally ended, he refused to hand over power. Again when his renewed presidency ended, he contimued to hold office illegitimately. The Showra-ye Nizar (Reconciliation and Reconstruction Council) was simultaneously formed despite the fact that it did not represent the majority of Parties and sections of society; and proceeded to renew once again Mr. Rabbani's term in office.

Those in office have continuously persisted to monopolise power at the cost even the lives of the people and the destruction of our country, and have resorted to any 
means to ensure this monopoly. It was to this end that the Showra-ye Nizar was formed, despite its rejection by the majority of the population and seven of the Mujahideen parties. The Islamabad Agreement which was signed by all despite its shortcomings, and which provided a formula for sharing power was also ignoted. When a meeting was reconvened in Jalalabad in order to agree on the practical means for applying the Istamabad Agreement, they |Rabbani-Massoud| attempted (0) sabotage the gathering. Mr Sayyaf manoeuvred his way out of the meeting and, with Massoud's co-operation, set about undermining the negotiations at Jalalabad by starting fighting in Parwan and Kapisa. When on 28 June |1994|, Mr. Rabbani's term ended, once again he insisted of remaining in office, recently organizing the partisan gathering at Herat. In fact, the gathering was so jneffective that both $\mathrm{Mr}$. Sayyaf and Mr. Rabhani himself refused to participate. Once it was realised that the gathering had failed to gain credibility both nationally and internationally, Mr. Rabbani who had gone to Herat refused to participate at the last minute. They have since initiated the instintion of another commission aimed at forming the Loya Jirga (Grand Elders' Council). The commission, however, is also partisan, and its outcome will not be accepted either by the other Parties of by the people of Afghanistan.

What all this points to is that they |Rabbani-MassoudSayyaf are unwilling to accept any resolution which requires the participation of all the peoples of Afghanistan, grants the people their rights, and allows the formation of a popular goverument and the restoration of peace.

The SCC was formed for the [dual] purpose of opposing the military and political efforts of this government to monopolize power, and to ensure the people's participation in the determination of their destiny. The SCC, a powerful opponent, represents the majority of the population of Afghanistan and can secure and guarantee the national unity of Afghanistan. Because the SCC strives to defind the people's rights and the formation of a government acceptable to the people, it is supportive of solutions which can secure a popular government and peace. It has always welcomed peace efforts by all parties |including|: M. Jalaluddin Haqani; Kabul's commanders; the OIC; and the UN [Special Mission] led by $\mathrm{Mr}$. Mohmoud Mestiri.

As it was hoped that Mr. Mohammed Mestiri's efforts would facilitate a solution and the formation of a popular government, and ensure peace, the SCC lent its sincere and serious support and co-operation to its progress.

They [the government] however opposed the UN peace efforts and attempted to sabotage it, for it was clear that it would put an end to their monopoly of power.

When Mr. Mestiri launched the second stage of his proposals, they [govermment] organised the Herat gathering irrespectively, and invited $\mathrm{Mr}$. Mestiri to participate at Herat. But since the Herat gathering was partisan, $\mathrm{Mr}$. Mestiri refused to participate. Following failure at Herat, they [the government] wasted time by offering false promises of co-operation to Mr. Mahmoud Mestiri. They even attempted to convince Mr. Mestiri to travel to Kabul in order to endorse the launch of the commission elected at the Herat gathering, in the hope of gaining credence for the gathering though his presence. Mr. Mestiri, however, who was well aware of the narrow base of the gathering. dismissed it as dominated by [the government] Kabul and not representative of the people of Afghanistan. They the govermment| nevertheless, and in complete disregard for the UN process, launched the conmussion's activities in Kabul on their own. Finally, they obstructed the UN process by refusing $\omega$ participate allegedly in opposition to the coparticipation of |General Dostom's| Jonbesh-e Melli-e Islami-e Afghanistan.

In a meeting with Mr. Mahmoud Mestiri in Islanabad on 2 sepiember 1994, convened in order to persuade them |the government| to join the peace process, we made 3 suggestions:

1. That Mr. Mesciri should make known to both the people of Afghanistan and the international community the developments and obstacles is negotiation of the past month.

2. To cut off the supply of banknotes printed illegally and without the support of bank reserves, which allow the continuation of war, to Kabul.

3. To suspend the office of Afghanistan's UN representative, which represents one party and not the people of Afghanistan, and to call on UN member countries io expel Afghanistan's representatives in ileir countries.

Mr. Mahmoud Mestiri has promised us to take measures to this end. They [govermment] have also caused the failure of the efforts of the neutral parties which have been active alongside Mr. Mahnoud Mestiri's plan. When the leaders of these parties travelled to Kabul, they were firstly unnecessarily detained in Kabul. And when they began their activities as appointed members of the commission for peace, they [the government] bombarded Charasyab and the headquarters of brother Hekmatyar, and detained temporarily one of the leaders in Kabul. Even though the government had itself endorsed their participation in the commission's activities, launched the commission in the absence of two of the appointed leaders still in Islamabad. The government's objection to negotiate with Jonbesh is an excuse, and the people of Afghanistan regard it as no more than political rhetoric, because Massoud and Mr. Rabbani rode into Kabul on Jonbesh tanks. Mr, Rabbani proclaimed General Dostom as a hero, brave mujahid and cherished son. He appointed General Dostom as Vice-President and Deputy Defence Minister. He officially recognised Jonbesh and included Jonbesh representatives in the Showra-ye Nizar. He asked Hazrat Mujaddedi to bring Jonbesh representatives along with him to Herat. He recently sent Maulawi Abdulbari as envoy in order to initiate negotiations with General Dostom who rejected it. Furthermore, when they [the government] can meet with |representatives] of India, enemy of Afghanistan's jihad, how can they refuse to meet with a fellow country man to negotiate for peace?

Mr. Rabbani's stance on this issue is unrealistic, because Jonbesh is an undeniable political, military and popular reality. Jonbesh enjoys the support of a large section of the population; without it peace can never return to the country. 
The SCC will continue to support any future efforts to establish a popular goverument acceptable to the entire population and to restore peace. We shall undertake every measure to secure peace in Afghanistan and the restoration of the people's right to determine their own destiny; we shall strive to this end.

\section{Supreme Islamic Co-ordination Council of Afghanistan.}

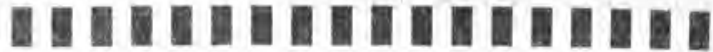

\section{UNESCO PLEA}

The following letter was kindly forwarded to us by one of our concerned readers, Dr. Schuyler Jones, Curator of the Pitt Rivers Museum, Oxford, to whom we are grateful.

A decade and a half of instability and war have inevitably. taken their toll on the cultural heritage of Afghanistan. one of the oldest and richest in. Asia. But while the previous regime represented the alien invader and could not therefore be expected to respect this heritage, one would have expected the Mujahideen government now in Kabul to value and strive to protect what remained of this heritage. However, we know (and have already reported on this) that not only is this is not the case, but this government has simply regarded Afghanistan's unique cultural artifacts as yet another resource to be plundered to fund the war.

The Wahdat Party is deeply saddened by this loss, and is supportive and grateful of all efforts to preserve and retrieve the country's cultural heritage.

\section{UNESCO}

7. Place de Fonteny

75352 Paris 07 SP

The Director-General

reference: DG 4.6/689

Dear Sir,

Dear Madam,

1 wish to draw your attention to the desperate situation of the Afghan cultural heritage as a whole and of the Afghan museum collections in particular.

War and pillaging have been devastating this unique heritage since 1980. The National Museum of Kabul, which was hit by several rockets has been plundered and the museum in Jellalabad was ransacked prior to its destruction. Many well-known Afghan artifacts have already appeared on the international art market and many more are expected to appear in the future. There is evidence that the international art market may be profiting from this illicit traffic.

To give but one recent example: During illicit excavations at Mir Zakah, an exceptional hoard of some 35,000 gold and silver coins was uncovered. UNESCO has been informed that the majority of the gold coins, which are in a better state of conservation than the silver ones, have already been sold to private collectors.
UNESCO is deeply concerned by the protection of the Afghan cultural heritage and I therefore wish to alert everyone, but especially museum officials, collectors and art dealers to be particularly cautious when considering the acquisition of cultural objects which might have originated in Afghanistan. I appeal to all those handling or acquiring these objects to respect scrupulously the interest of the Afghan people by avoiding the acquisition of objects which may have been stolen from them.

An inventory of the Kabul Museum exists in the Musee Guimet in Paris. In addition, descriptions, of many objects liave been published in a number of reviews and books. Anyone offered a cultural artifact which may have come from Afghanistan is urged to write to the International Standards Section of the Division of Physical Heritage of UNESCO, I rue Miollis, 75732 Paris Cedex 15, France.

Your co-operation is essential if Afghanistan's museum collections are to be reconstituted. It will be most deeply appreciated.

Yours faithfully

Federico Mayor

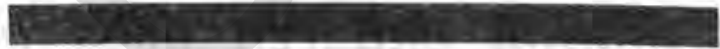

\section{REFUGEE UPDATE}

\section{Statement by Wahdat Party in Response to the Governor of Khorassan (Iran)}

The barbaric Soviet invasion [of Afghanistan] represents one of the gravest and most tragic of the present century, resulting in millions of martyrs, hundreds of thousands of war-wounded and total destruction inside Afghanistan, along with the forced migration of millions of refugees to countries throughout the world.

Muslim nations, in particular the Islamic Republic of Iran, have over the 14 years of the jihad by the muslim nation of Afghanistan, not only provided much material and spiritual support, but played host to millions of Afgahni refugees, for which we are grateful.

Doubtless the presence of some 2 million Afghani refugees must have led $t$ the creation of certain problems; it is inevitable that some from amongst this number have committed mistakes and crimes. Just as amongst every nation, however stable and regardless of stability and circumstances, corruption and crime persist, including in the Islamic Republic of Iran which despite much effort has not yet succeeded in removing sources of corruption from its society. In view of this and the difficult conditions of life experienced by Afghani refugees in Iran and Pakistan, the statistics available show a relatively small incidence of such crimes and corruption, in comparison to many other countries.

Unfortunately, the exaggerated and unfounded claims of corruption and criminality amongst Afghani refugees made by $\mathrm{Mr}$ Mofidi, Governor of Khorassan, recently reported by the [Iranian] daily, 'Abrar', are far from reflective of the reality and of Islamic principles, and contrary to humanitarian compassion. The Islamic Wahdat Party of Afghanistan condemns Mr. Mofidi's irresponsible and 
unfounded claims, and considers these a direct insult to the people of Afghanistan, in particular to decent and hardworking Afghani refugees; and requests of the Islamic Republic of Iran, in particular of authorities at the Ministry of Interior, to clarify the policy of the Islamic Republic of Iran ilf siew of Mr. Mofidi's comments, and to abstain frổm any comments and stances which would damage fraternal and friendly relations between the two mujahid nations of Afghanistan and Iran.

Istamic Wahdat Party of Afghanistan,

2/6/1373 (24/8/1994)

\section{"800 killed, 17,000 wounded in last 4 weeks of fighting in Kabul"}

\section{"3-4 million children dead of malnutrition in 15 years"}
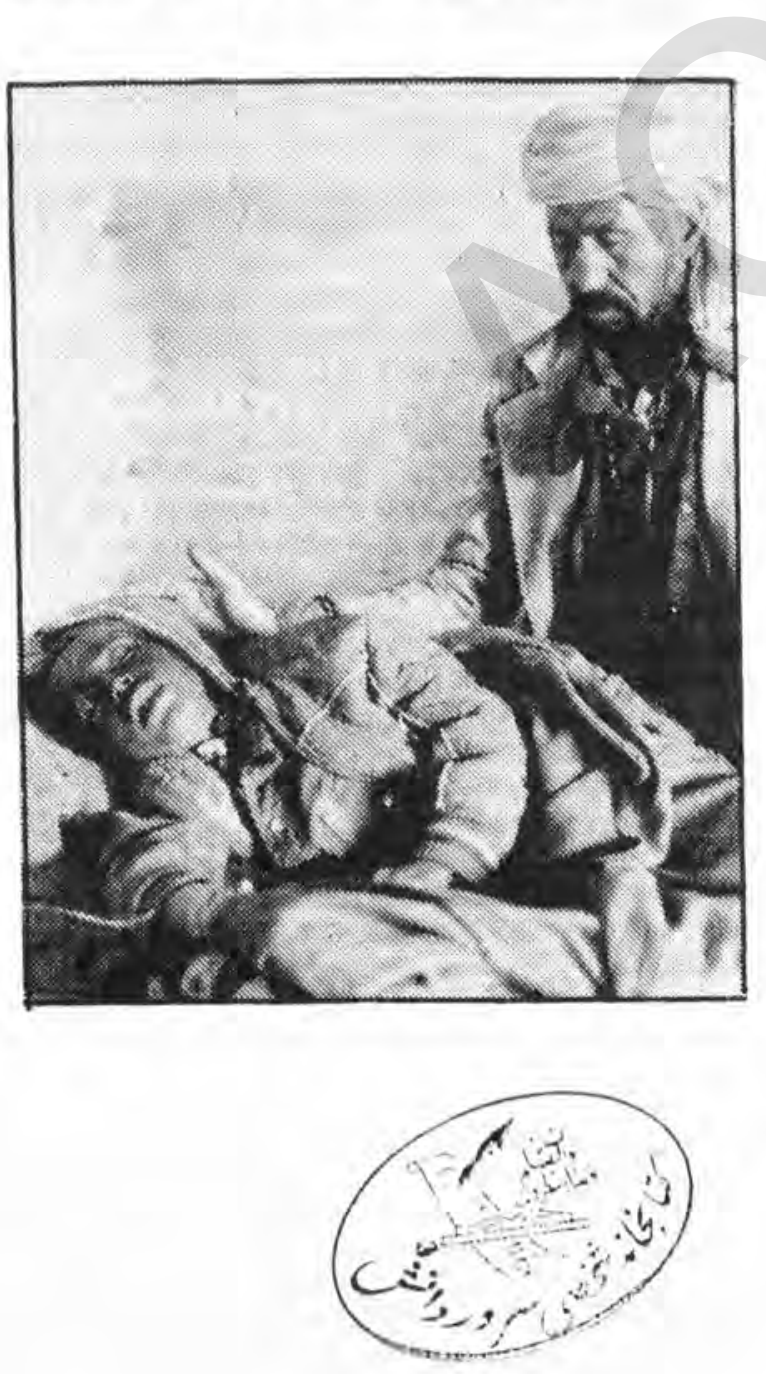

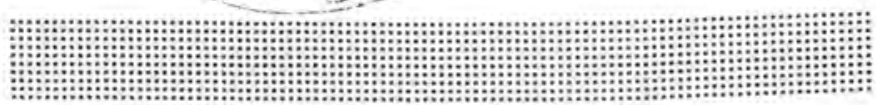

\section{AFGHAN WOMAN SETS HERSELF ABLAZE}

An Afghan woman died after setting fire to herself in front of the office of the United Nations High Commission for Refugees in New Delhi on Monday. Her suicide astonished UNHCR staff.

VOA correspondent, Lee Desmond, said the reason for her action was not known. Some Afghans living in New Delhi have interpreted it as a protest against the UNHCR, aimed at drawing the attention of concerned officials to the problems being faced by Afghan refugees in India.

According to estimates by UN officials, there are at least 24,000 Afghan refugees in India. They have formed an organization, and have staged several demonstrations in front of the UN office in protest over the decision to cut the amount of stipend received by them.

Rajiv Kapoor, Deputy Chief of the UNHCR at New Delhi, said the cases of refugees who had arrived before 1992 were reviewed by his office last year. At least five out of 15,000 cases were found where assistance was no longer required because the refugees were receiving income from other sources. They continue to receive medical aid and assistance with school fees.

However, a spokesman of the autonomous organization, South Asian Human Rights Documentation Centre, Ravi Nayyar did not agree with $\mathrm{Mr}$ Kapoor's findings. He said surveys carried out by his centre showed that the UNHCR was dragging its foot in performing its duties as a relief organization, and seemed to be more concerned with pleasing the Indian government.

Mr Nayyar said the UN was forcing the refugees into the position of either being compelled to return to Afghanistan or seeking refuge in other countries, even by illegal means.

Islamic Wahdat Party of Afghanistan (UK), 35 Cowan Court, Ayres Crescent, London NW 10 8DS. Fax: (081) 9614212

Subscription:

UK \& EC 1 Year 6 Months Others $\begin{array}{ll}£ 10 & £ 6 \\ £ 15 & £ 8\end{array}$

(Incl. P\&P) 